\title{
IMPACT OF FERRO-SILICON AND GYPSUM ON THE RECOVERY OF COPPER FROM COPPER SLAG
}

\author{
Junior Ngoy KAYEMBE, Michel Kalenga WA KALENGA, Didier Kasongo NYEMBWE \\ Department of metallurgy, school of mining, metallurgy and chemical engineering, Faculty of Engineering \\ and Built Environment, University of Johannesburg, South Africa \\ jkvert@gmail.com, dnyembwe@uj.ac.za, michelk@uj.ac.za
}

https://doi.org/10.37904/metal.2019.923

\begin{abstract}
High demand in metals coupled with the depletion of metal reserves, slag has become a second source. The demand in copper remaining high while Copper mines are being lesser are lesser, any treatable copper source are targeted. The current investigation focuses on the impact of ferro-silicon and gypsum collected from hydrometallurgical plants both to favour the formation of matte and. Carbon monoxide was blown in at 0.04 $\mathrm{I} / \mathrm{min}$ for reduction. The head samples and products were characterized using XRF, XRD and SEM. The copper slag, ferrosilicon and gypsum were crushed and milled together for $15 \mathrm{~min}$ to obtain a homogeneous head sample. An alumina tube furnace set at $1400{ }^{\circ} \mathrm{C}$ was used for the experiment. Based on previous work, the basicity was kept at 0.7 through gypsum addition. The sample was kept for two hours in the furnace at the set temperature and the furnace was switched-off to cool down slowly. A graphite crucible was used. The little matte observed in the head sample entrapped from previous matte production. However, the final produced slag showed more matted formed collecting more copper with high iron content, thus low copper grade due to ferrosilicon addition. Although the distinction between the new matte and new slag was a challenge due to the matte layer very thin, the recovery of copper from the slag was successful. The correlation between the amount of ferrosilicon and the matte grade was found to be inverse proportional due to the amount of iron added through ferrosilicon. Also, the role played by gypsum both on the formation of copper matte and as a flux was very effective in copper coupled with good slag-matte immiscibility. The characterized raw Cu slag showed trace of $\mathrm{Ge}$ in the SEM-EDS results and a fayalitic slag containing some little matte.
\end{abstract}

Keywords: Impact ferro-silicon, copper recovery, gypsum

\section{INTRODUCTION}

Copper slag is a main by-product produced from of copper ores smelting during the copper pyrometallurgy process [1]. This material is confidently a secondary source valued metallic at economic concentrations. Therefore, Copper slag can be processed as a secondary raw material due to its usual substantial amount of copper and other valuable metals [2,3]. In recent years, several approaches have been extensively carried to recover these metals and gave promising results [4]. In the basic slags containing FeO-SiO2 system, the influence of commonly found compounds $\mathrm{CaO}-\mathrm{Fe}_{3} \mathrm{O}_{4}-\mathrm{Cu}_{2} \mathrm{O}$ on the viscosity and conductivity have been investigated. It was found that the transition of the basic slag was favoured by $\mathrm{CaO}-\mathrm{Fe}_{3} \mathrm{O}_{4}-\mathrm{Cu}_{2} \mathrm{O}$ which made the viscosity and conductivity difficult to understand since it was alleged that there is a correlation between the viscosity and the conductivity [5]. A number of studies on the copper slag to recover copper and additional base metals have been conducted using hydrometallurgical route. A recovery of base metals from copper smelter slag was conducted by leaching the slag with sulfuric acid and sodium chlorate oxidant by neutralizing through the addition of calcium hydroxide. This was done without roasting. Results have shown a very good recovery [6]. An investigation on the recovery of zinc, copper and iron was conducted using a brass slag. Leaching using sulfuric acid coupled with precipitation, an efficient separation method was established [7]. 
With the view of cleaning the environment, a secondary copper slag was carbothermally reduced. Results have shown that a slag considered as a waste could be successfully processed to obtain reusable products [8]. A proposition on processing a copper slag was put forward with steps comprising an oxidation of slag using air followed by hydrothermal treatment using sodium hydroxide, solid-liquid separation, hydrolysis of the liquid silicate and drying. Results revealed that the combination of the above steps led to an appropriate gel formation [9].

To support carbon monoxide reduction of germanium dioxide, ferro-silicon is added to the sample. The ferrosilicon was expected to favour not only the formation of matte but also to free germanium from silicates matrix. The reduced copper and germanium, sulfurized with $\mathrm{SO}_{2}$ through the addition of $\mathrm{CaSO}_{4}$ together with other reduced metals like iron from the slag to form a matte.

\section{METHODOLOGY}

\section{Materials}

The copper slag sample used in the current study was obtained from a copper smelter plant Gecamines in Lubumbashi, in Katanga province (Democratic Republic of Congo).

\section{Experimental procedure}

The raw slag was characterized using XRF, XRD and SEM-EDS then mixed with $\mathrm{CaSO}_{4}$ (gypsum) to increase the basicity to 0.7 and different amounts of ferro-silicon of $0.005 \mathrm{~g}, 0.006 \mathrm{~g}, 0.007 \mathrm{~g}, 0.008 \mathrm{~g}$. The mixture was put into graphite crucible then placed in the hot zone of the tube furnace. Carbon monoxide gas was blown in the furnace at a rate of $0.4 \mathrm{l} / \mathrm{min}$ from $600{ }^{\circ} \mathrm{C}$ in to the working temperature of $1400{ }^{\circ} \mathrm{C}$ to create reducing conditions. An alumina tube furnace, Elite had a heating rate of $7{ }^{\circ} \mathrm{C} / \mathrm{min}$ was used for the current study. After the furnace reached the set temperature, the samples were kept in the furnace for 2 hours, then the furnace was switched off for slow cooling. The products were analyzed through XRD and SEM-EDS.

\section{RESULTS AND DISCUSSION}

The chemical composition of the slag is provided in Table 1 below.

Table 1 Chemical composition of the cobalt bearing slag

\begin{tabular}{|c|c|c|c|c|c|c|c|}
\hline Element/Compound & $\mathrm{SiO}_{2}$ & $\mathrm{CaO}$ & $\mathrm{MgO}$ & $\mathrm{Al}_{2} \mathrm{O}_{3}$ & $\mathrm{Fe}$ & Co & Basicity \\
\hline (wt\%) & 31.1 & 16.1 & 4.9 & 6.2 & 37.7 & 1.38 & 0.56 \\
\hline
\end{tabular}

Basicity $=(\% \mathrm{CaO}+\% \mathrm{MgO}) /\left(\% \mathrm{SiO}_{2}+\% \mathrm{Al}_{2} \mathrm{O}_{3}\right)$

The phases found in raw sample are presented in Figure 1 below. The XRD pattern was obtained thanks to the OriginPro 8.5 that allowed the decomposition of picks for better identification of phases. The decomposed XRD spectrums of the head sample provided different phases containing spinel, copper aluminate spinel, iron silicate namely fayalite, cobalt oxide and different spinel phases.

The presence of magnetite could be justified because some hematite during matte production in the water jacket furnace was reduced to magnetite although coke was added essentially for combustion purposes to provide the necessary heat to decompose chalcopyrite. Magnetite is generally avoided due to its high melting temperature that renders the viscosity of the slag high with the consequence of easily decreasing the volume 
of the furnace because. Also, magnetite is known for its corrosiveness behavior toward refractories, hence its formation needed to be limited.

The presence of pyrite could be presumably due to matte entrained during either matte taping or slag taping step. However, this was certainly a very small amount of matte that was present in the slag unless the operations over the water-jacket furnace was not efficient when this slag was produced.

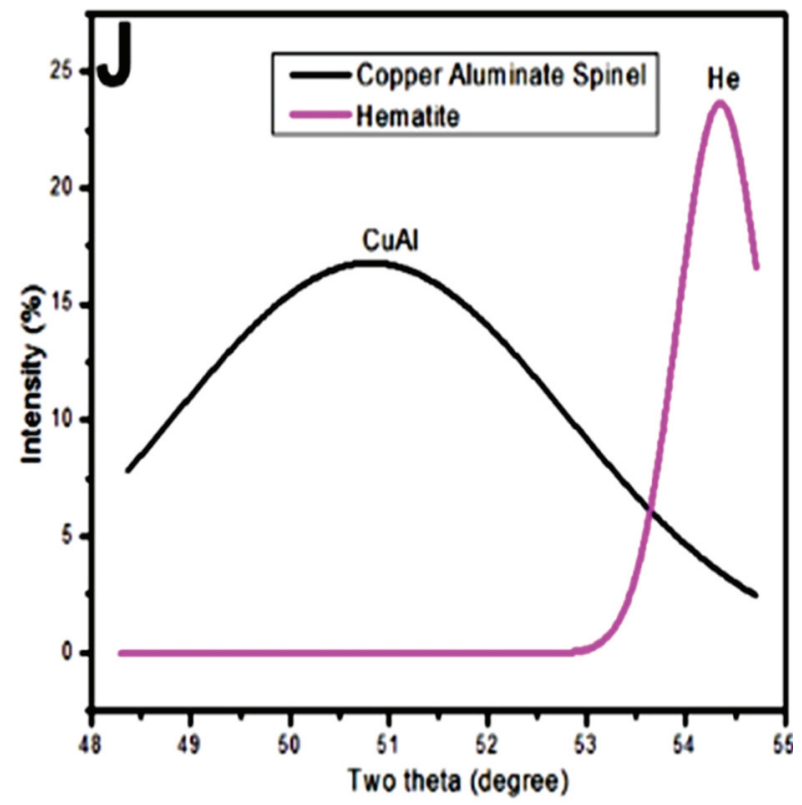

(a)

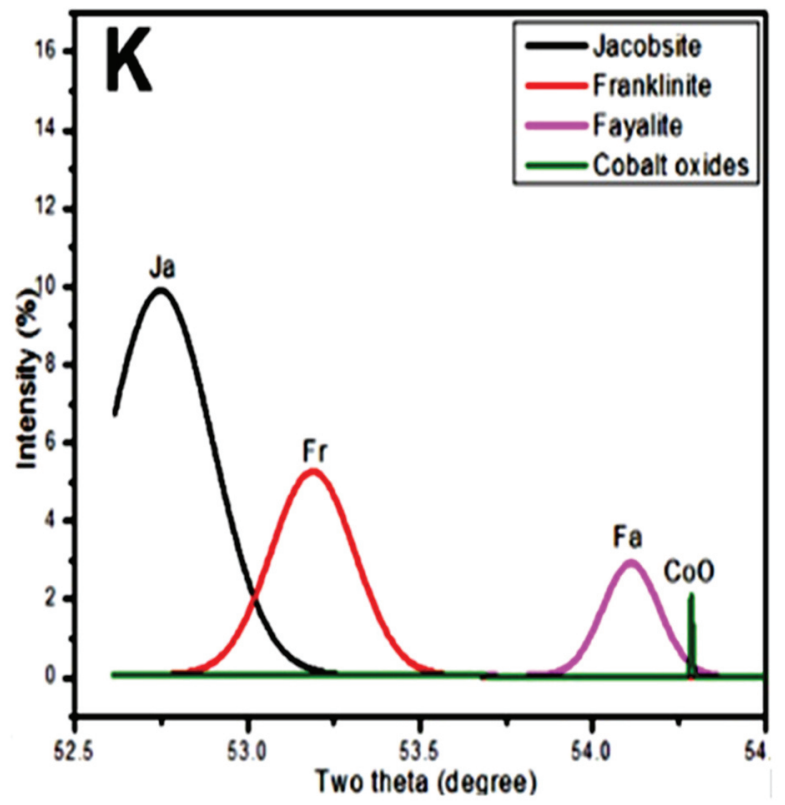

(b)

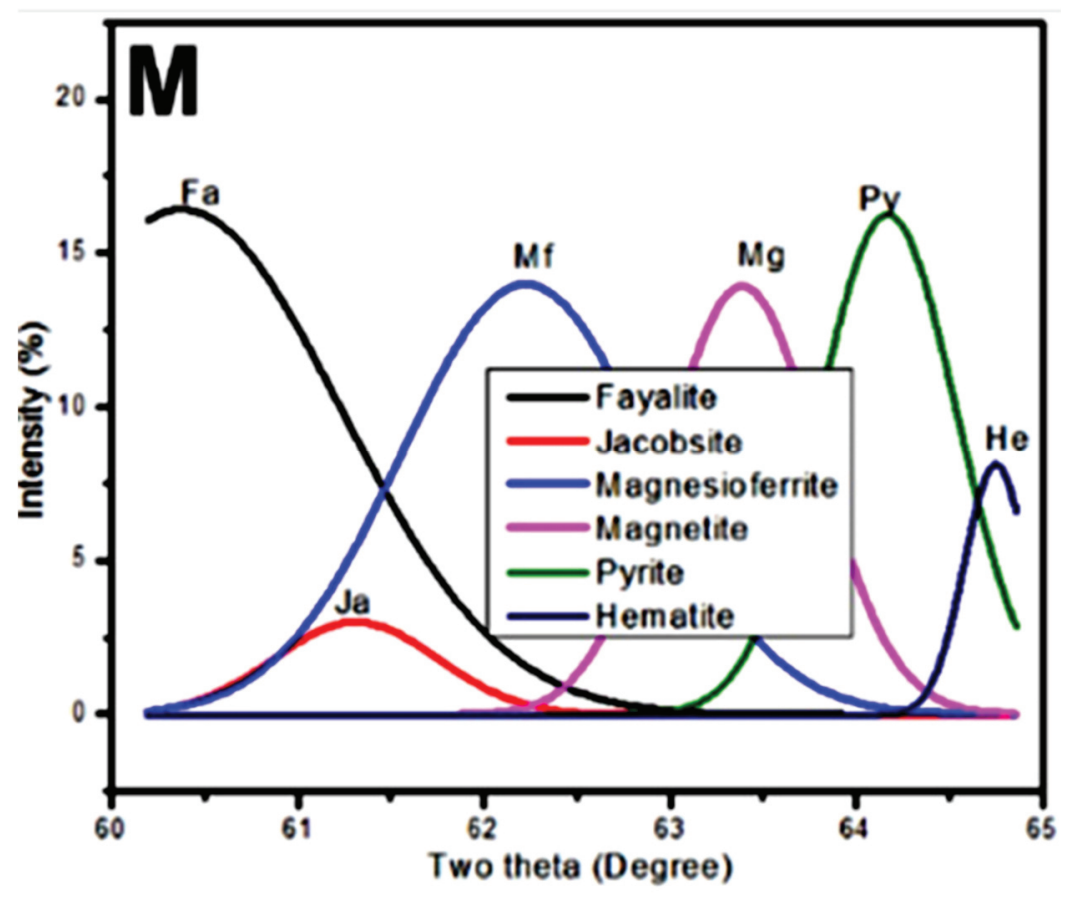

(c)

Figure 1 Decomposed XRD pattern of head sample [10] 


\section{SEM-EDS of the raw slag}

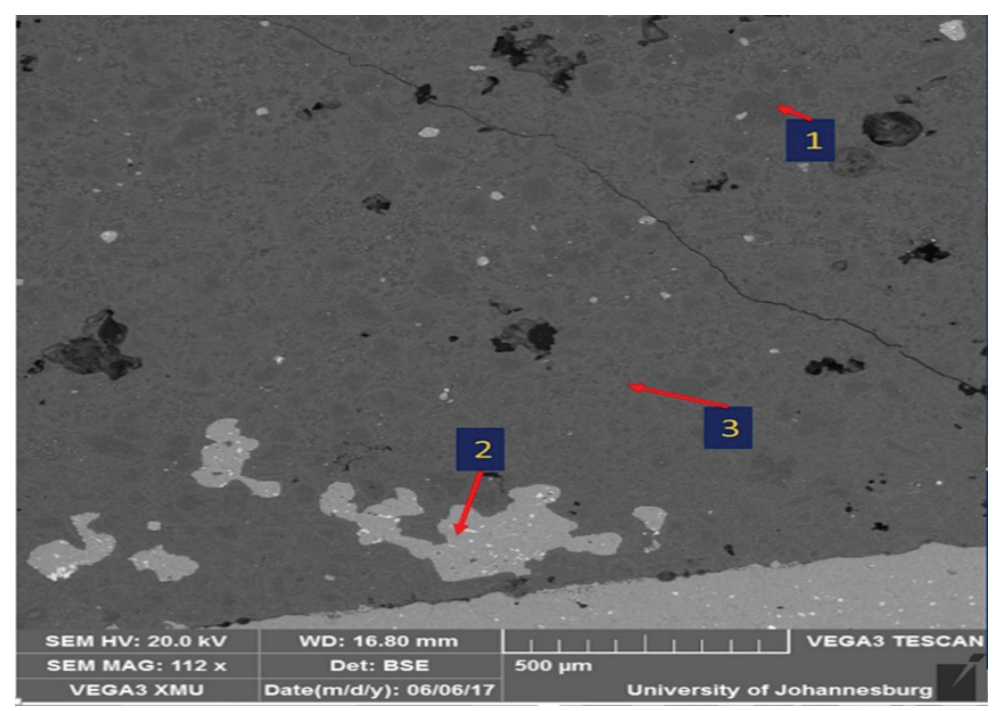

\begin{tabular}{|l|r|r|r|}
\hline & 1 & 2 & 3 \\
\hline $\mathrm{El}$. & \multicolumn{3}{|c|}{$\%$} \\
\hline $\mathrm{Mg}$ & 15.1 & & 12.6 \\
\hline $\mathrm{Si}$ & 17.8 & & 17.7 \\
\hline $\mathrm{Ca}$ & 0.47 & & 0.69 \\
\hline $\mathrm{S}$ & & 15.2 & 0.02 \\
\hline $\mathrm{Fe}$ & 17.9 & 0.32 & 20.0 \\
\hline $\mathrm{Co}$ & 5.94 & 0.34 & 6.33 \\
\hline $\mathrm{Cu}$ & & 48.9 & \\
\hline $\mathrm{Zn}$ & 4.52 & & 5.07 \\
\hline $\mathrm{O}$ & 38.3 & 35.2 & \\
\hline $\mathrm{Ge}$ & & & 0.2 \\
\hline
\end{tabular}

Figure 2 Raw slag SEM-EDS representation (in wt\%)

Figure 2 provided the composition on chosen spots. It should however be noted that the focus was more on the elements that would be of influence on the process. Although the results would not be very much representative since only three spots were analyzed, the presence of copper, zinc, germanium, iron was confirmed. The presence of sulfur was linked to possible matte that was entrained during taping of the slag. The amount of germanium in the sample was very low. This was expected since from the ore germanium was already in particle per millions.

\section{Smelted samples}

In Figure 3 were the samples of products after smelting and placed upside down. The mattes could easily be seen shine on the surface of the samples. However, some matte could be also seen trapped in the slag at the peripheral discs surrounding the matte. This showed that some matte did not settle completely and remained trapped in the slag. Further, it was important to note that since the head sample did show much the presence of trapped matte apart of the pyrite that was identified, the matte in the smelted samples were therefore including the little matte that came with the head sample.
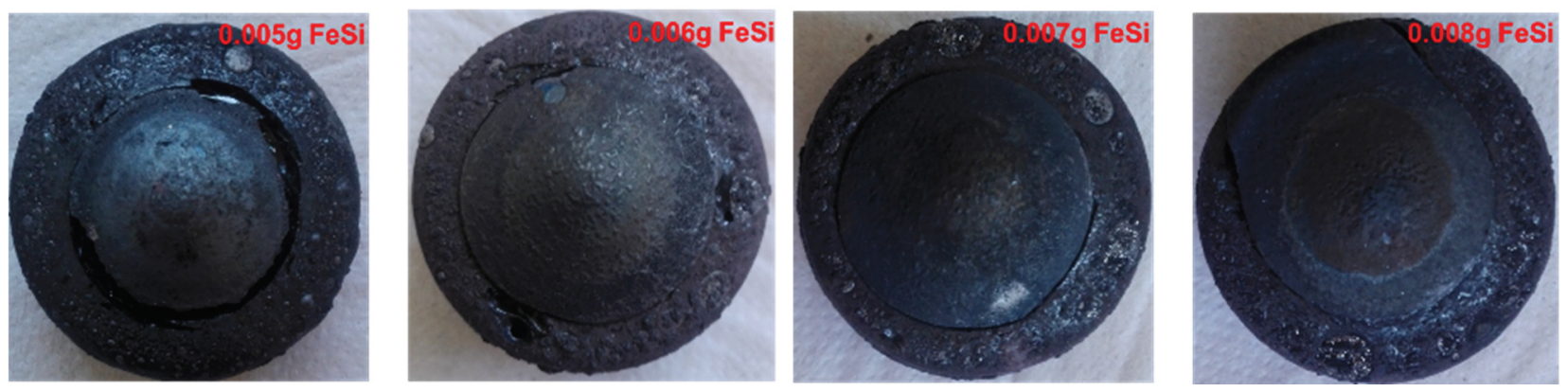

Figure 3 samples after reduction in presence of different amounts of ferro-silicon

\section{XRD}

Figure 4 above presents the phases in the mattes produced with different amounts of ferro-silicon added. It was observed that at $0.005 \mathrm{~g} \mathrm{FeSi}$, germanium essentially attached to iron. This confirmed the germanium siderophile character. Also the formation of $\mathrm{FeS}$ in the matte was confirmed. At $0.006 \mathrm{~g} \mathrm{FeSi}$, the iron germinide 
phase appeared alone and mostly associated to sulfur in form of FeGeS. This was presumably due to the displacement of germanium from the silicate matrix in the slag to the matte since silicon replaced germanium in the matrix. Also, germanium appeared in copper germanium sulfide phase (CuGeS). This showed a chalcophile behavior of germanium. Both siderophile and chalcophile were observed at $0.007 \mathrm{~g} \mathrm{FeSi}$ in $\mathrm{CuFeGeS}$ phase. At $0.008 \mathrm{~g} \mathrm{FeSi}$, germanium sulfide was observed probably because the sulfur exchanged with other metals.

Mattes

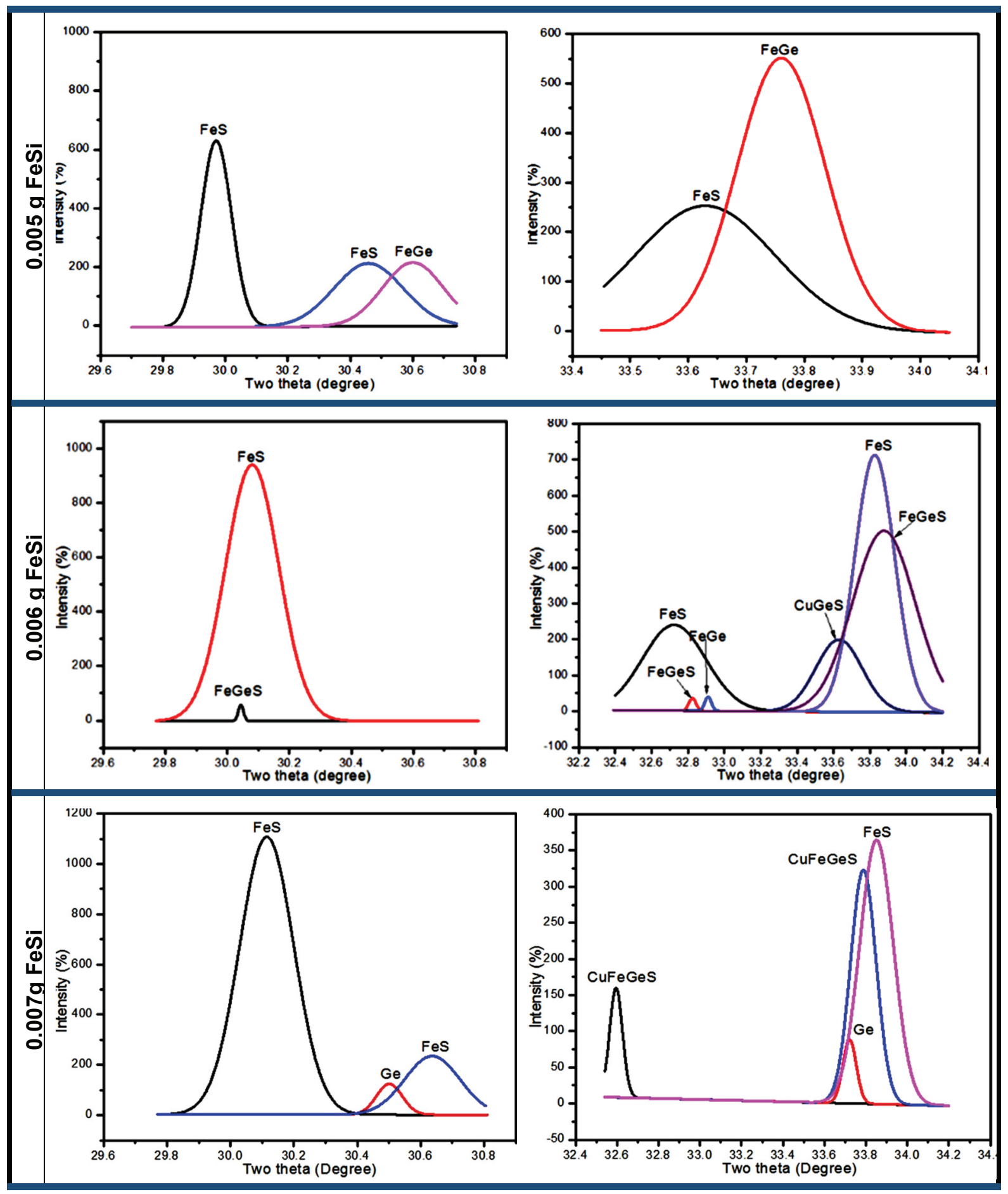

Figure 4 Decomposed pattern presenting germanium phases 


\section{Slags}

The new slags produced with $0.007 \mathrm{~g}$ and $0.008 \mathrm{~g}$ FeSi addition were highly amorphous and could not show any peak during XRD processing reason why they were not presented in the Figure $\mathbf{5}$ below. The addition of gypsum has shown a considerable effect on the phases that formed in the slag. This explained a relatively good immiscibility between the slag and the matte produced. The abundance of phases containing calcium oxide confirmed this.
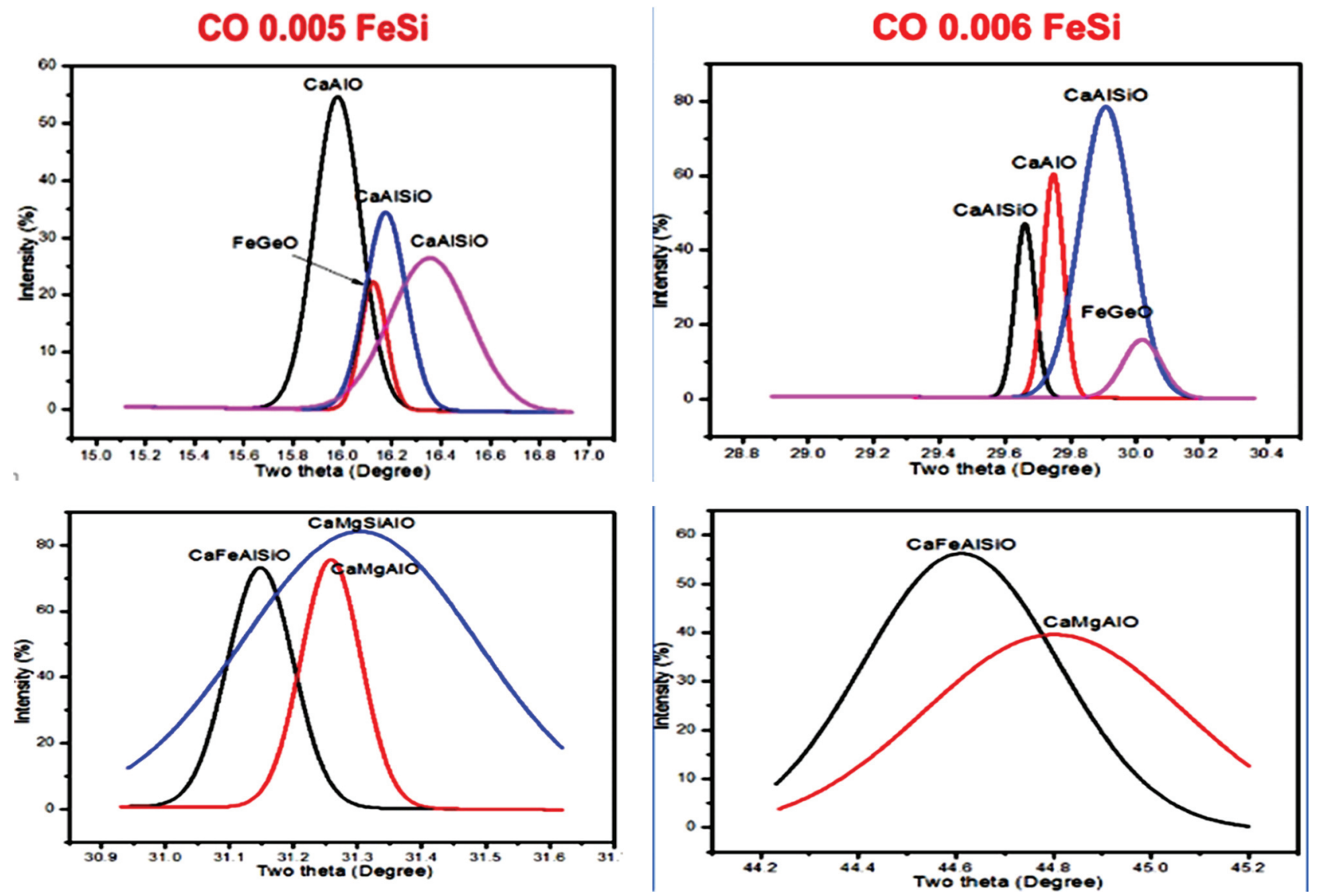

Figure 5 XRD patterns of new slags produced presenting the new phases

\section{SEM-EDS}

The SEM-EDS presented the cross-section of the matte inverted at the top and the corresponding chemical composition of the analyzed zone at the bottom left of the Figure 6 a showing the distribution of elements throughout the matte.

The results presented have been generated based on the distance from the top of the matte. Images and tables from L1 to L8 are related to the matte whereas the points 1 to 21 are related to the slags produced at different FeSi amounts added. It was observed three thin layers of slightly different mattes. The percentages demonstrated that $\mathrm{Cu}$ and $\mathrm{Fe}$ were dispersed throughout all the mattes. On the other hand, sulfur was highly concentrated in the top layers. This was presumably due to the rich sulfur interface matte-slag. These two facts could be the reason for the formation of two phases in the mattes.

From Figure $6 \mathbf{b}$, the SEM on the new slags, it was observed that a bit of MgO dissolved into the slag as elemental Mg proved. Silica and calcium oxide were the main oxides in the slag. This found its explanation through the addition of gypsum that was added to modify the basicity and as a source of sulfur to favour the formation of matte. Also, iron was one of the major elements present in the slag as oxide. This was due to the 
iron that came from the original slag that remained as oxide without being converted into sulfides. Also, some copper remained into the slag as oxides. However, the presence of sulfur could be due to some matte that remained in the slag unsettled therefore dissolved in the slag.

\begin{tabular}{|c|c|c|c|c|c|c|c|c|c|c|c|c|c|c|c|c|}
\hline \multicolumn{17}{|c|}{ Mattes } \\
\hline \multicolumn{5}{|c|}{0.005} & \multicolumn{4}{|c|}{0.006} & \multicolumn{4}{|c|}{0.007} & \multicolumn{4}{|c|}{0.008} \\
\hline \multicolumn{5}{|c|}{ 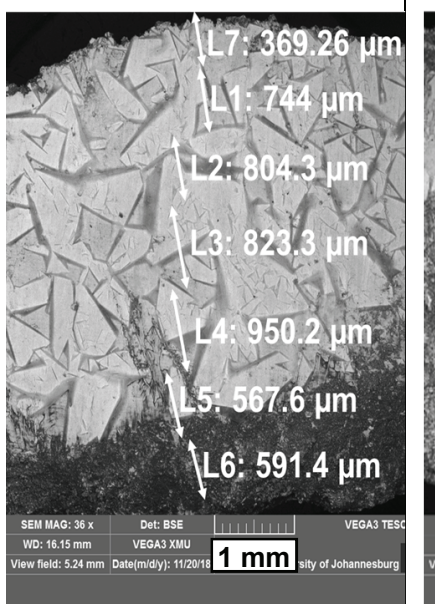 } & \multicolumn{4}{|c|}{ 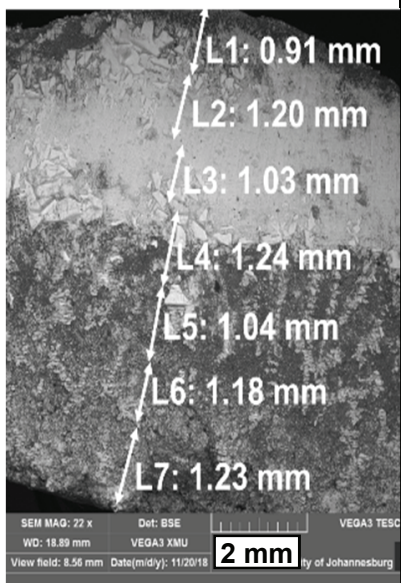 } & \multicolumn{4}{|c|}{ 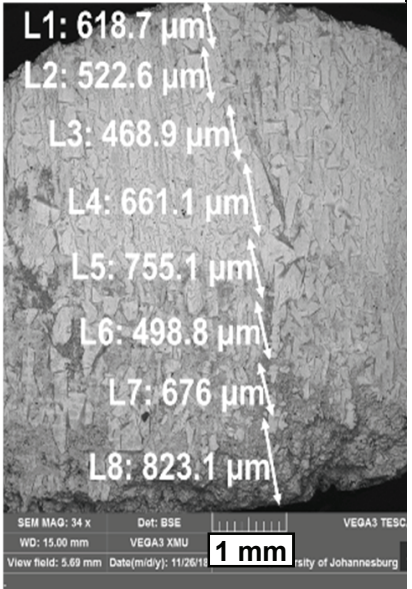 } & \multicolumn{4}{|c|}{ 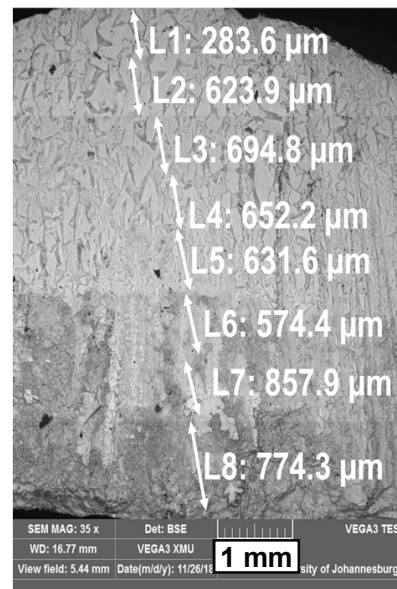 } \\
\hline \multicolumn{17}{|c|}{ Mattes } \\
\hline & \multicolumn{8}{|c|}{0.005} & \multicolumn{8}{|c|}{0.006} \\
\hline$\%$ & L1 & L2 & L3 & L4 & L5 & L6 & $\mathrm{L} 7$ & L8 & L1 & $\mathrm{L} 2$ & L3 & L4 & L5 & L6 & $\mathrm{L} 7$ & L8 \\
\hline $\mathbf{P}$ & 2.11 & 1.71 & 1.89 & 1.96 & 1.36 & & 2.26 & & 1.42 & 4.71 & 2.13 & 4.63 & 4.14 & 1.32 & 0.46 & \\
\hline $\mathbf{S}$ & 14.9 & 19.7 & 17.7 & 14.8 & 15.4 & 28.8 & 14.3 & & 11.8 & 8.0 & 15.9 & 8.8 & 8.5 & 21.9 & 29.0 & \\
\hline $\mathrm{Fe}$ & 89.0 & 63.1 & 65.2 & 70.8 & 67.4 & 41.7 & 69.8 & & 60.5 & 75.4 & 69.9 & 76.6 & 75.3 & 61.7 & 53.6 & \\
\hline Co & 3.82 & 3.18 & 3.55 & & & & 4.16 & & 8.87 & 7.38 & 8.28 & 7.62 & 7.17 & 4.86 & 3.12 & \\
\hline $\mathrm{Cu}$ & 10.2 & 12.3 & 10.8 & 10.6 & 11.2 & 16.7 & 9.52 & & 10.8 & 3.75 & 5.83 & 3.57 & 4.39 & 9.35 & 12.6 & \\
\hline $\mathrm{Si}$ & & & 0.38 & 0.42 & 0.83 & 2.08 & & & 4.90 & 0.80 & & 0.82 & 0.55 & 0.93 & 1.22 & \\
\hline $\mathrm{Ca}$ & & & & & 0.43 & 1.58 & & & 1.89 & & & & & & & \\
\hline $\mathrm{Ti}$ & & & & & 0.36 & 1.40 & & & & & & & & & & \\
\hline Al & & & & & 0.57 & 1.23 & & & & & & & & & & \\
\hline & \multicolumn{8}{|c|}{0.007} & \multicolumn{8}{|c|}{0.008} \\
\hline $\mathbf{P}$ & 2.84 & 2.82 & 2.97 & 2.72 & 0.8 & 0.28 & & & 4.59 & 4.88 & 4.42 & 4.87 & 3.21 & & & \\
\hline $\mathbf{s}$ & 11.3 & 11.1 & 10.3 & 12.0 & 21.8 & 27.7 & 25.5 & 26.8 & 8.04 & 5.43 & 7.42 & 10.9 & 14.8 & 29.6 & 29.15 & 32.8 \\
\hline $\mathrm{Fe}$ & 71.4 & 72.2 & 73.2 & 71.5 & 58.1 & 50.2 & 53.6 & 50.8 & 76.7 & 79.6 & 77.6 & 74.1 & 69.4 & 52.4 & 53.1 & 50.5 \\
\hline Co & 8.57 & 8.85 & 7.01 & 8.5 & 4.29 & 2.77 & 3.44 & 2.58 & 8.24 & 6.82 & 8.44 & 5.86 & 5.2 & 2.37 & 2.25 & \\
\hline $\mathrm{Cu}$ & 8.07 & 7.38 & 8.81 & 7.23 & 14.8 & 18.5 & 16.5 & 17.9 & 4.39 & 3.27 & 4.11 & 4.85 & 7.41 & 15.7 & 15.8 & 18.8 \\
\hline Si & & & & & 0.24 & 0.29 & 0.42 & 0.75 & & & & & & & & \\
\hline $\mathrm{Ca}$ & & & & & & & & 0.21 & & & & & & & & \\
\hline
\end{tabular}

Figure 6 a) SEM-EDS of mattes 


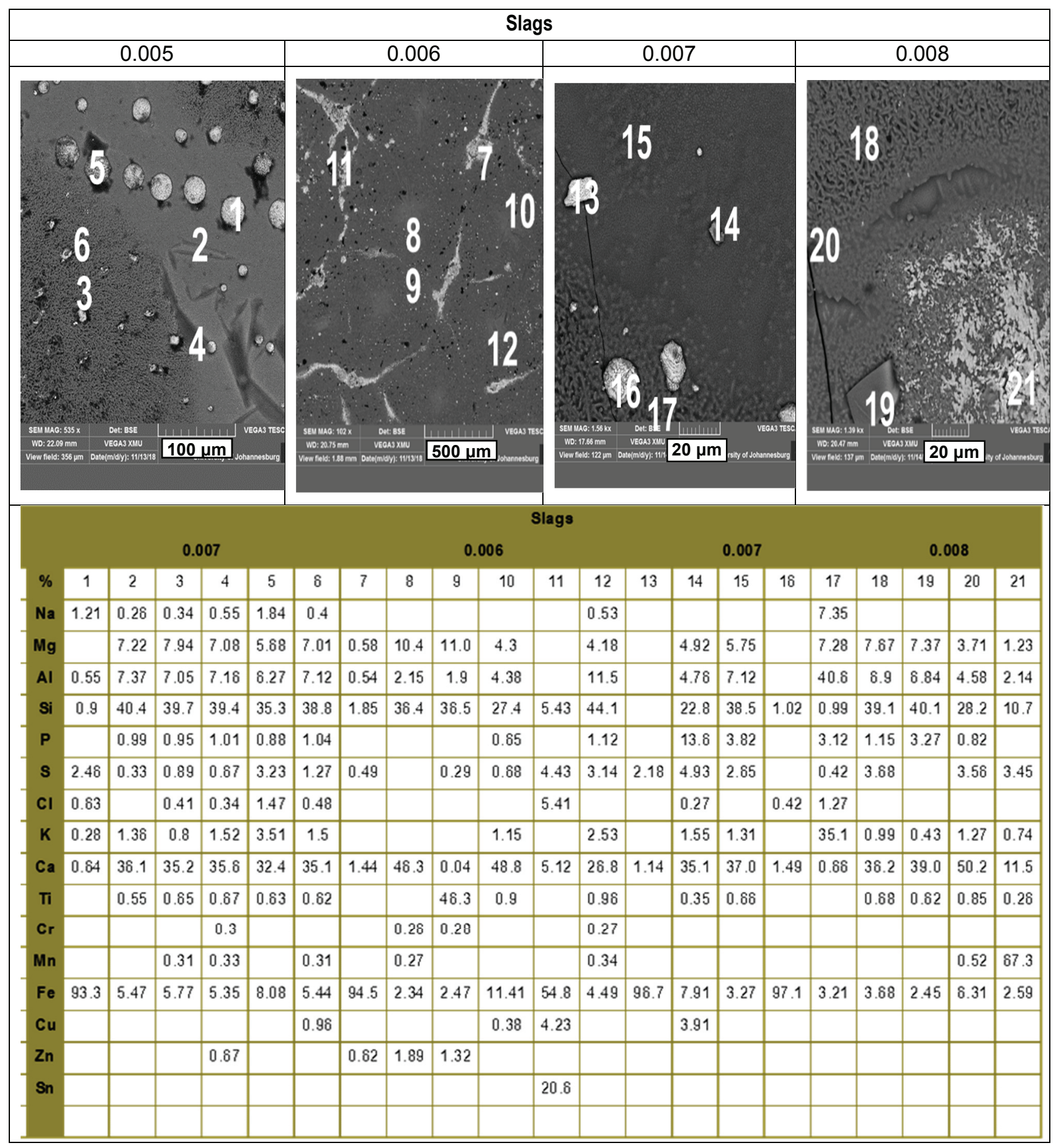

Figure 6 b) SEM-EDS of new slags

\section{CONCLUSION}

The aim of this experiment was to investigate the impact of ferro-silicon addition on the reduction of Ge-Copper bearing slag and the possible effect of gypsum dumped from hydrometallurgical plants. Following conclusions were drown:

1) Three layers of mattes were identified. The bottom layer was rich in iron and copper, the middle matte contained, on top of iron and copper, cobalt. The top matte contained more iron than other two namely copper and cobalt 
2) The characterized raw slag has shown Ge through SEM and a fayalitic copper slag. The smelting of slag at different amount of FeSi coupled with the reduction and the addition of gypsum allowed the formation of copper matte that contained germanium. The mattes presented Ge phases associated with or always next to an iron phase evidencing the siderophile behavior.

3) The new slags produced at law amount of FeSi have shown the presence of a Ge-oxide (FeGeO) and a main oxide of $\mathrm{CaAISiO}$ with a variation of $\mathrm{FeO}$ and $\mathrm{MgO}$ in it. The presence of many phases containing calcium oxide confirmed that the addition of gypsum decomposed and played an important role in the modification of the structure of the final slag therefore weakening the silica bonds to allow the transfer of germanium to the matte as well as the transfer of copper to the matte via reduction. Also, the use of gypsum as sulfurizing agent proved to be efficient in the conversion of copper and iron oxides into sulfides.

4) The storage or dumping of gypsum that posed a threat to the environment have been attended to efficiently since it will serve in the pyrometallurgical industry in the recycling of copper slag. This had avoided a possible formation of sulfuric acid that could form during rainy season or at a place where moisture is present, this with all the drastic consequences on the environment.

\section{ACKNOWLEDGEMENTS}

\section{The authors would like to thank Gecamines (from the DRC) for providing the copper slag sample and their support and acceptation to collaborate with our team.}

\section{REFERENCES}

[1] WARZOK, A. and RIVEROS, G. Slag Reducing and Cleaning with Calcium Carbide, Cu. The Carlos Díaz Symposium on Pyrometallurgy, Toronto, Canada. 2007. vol. 3, book 2, pp. 379-390.

[2] BOOM, R., MILLS, K.C. and RIAZ, S. Recent trends in research on slags. In Proceedings of the Sixth International Conference on Molten Slags, Fluxes and Salts. Stockholm, Sweden-Helsinki, Finland, 12-17. 2000. CD Rom-paper 110.

[3] SÁNCHEZ, M., PARADA, F., PARRA, R., MARQUEZ, F., JARA, R., CARRASCO, J.C. and PALACIOS, J. Management of copper pyrometallurgical slags: giving additional value to copper mining industry. In VII International Conference on Molten Slags Fluxes and Salts, Proceedings, 2004. pp. 543-550.

[4] LI, Y., PEREDERI, I. and PAPANGELAKIS, Y.V.G. Cleaning of waste smelter slags and recovery of valuable metals by pressure oxidative leaching" Journal of Hazardous Materials. 2008. vol. 152, pp. 607-615.

[5] ZHANG H., SUN F., SHI X., ZHANG B. and HONG X.The viscous and conductivity behaviour of melts containing iron oxide in the $\mathrm{FeO}_{\mathrm{t}}-\mathrm{SiO}_{2}-\mathrm{CaO}-\mathrm{Cu}_{2} \mathrm{O}$ system for copper smelting slags. The Minerals, Metals \& Materials Society and ASM International. 2012. vol. 43B, pp. 1046-1053.

[6] ZhangYANG, Man RUI-LIN, Ni Wang-DONG and Wang HUI. Selective Leaching of base metals from copper smelter slag. Hydrometallurgy Journal. 2010. vol. 103, iss. 1-4, pp. 25-29.

[7] AHMED, I.M., NAYL, A.A. and DAOUD, J.A. Leaching and recovering of Zinc and Copper from brass slag by sulfuric acid. 2016. vol. 20, supplement 1, pp. S280-S285.

[8] SARFO, P., DAS, A., WYSS, G. and YOUNG, C. Recovery of metal values from copper slag and reuse of residual secondary slag. Waste Managment Journal. 2017. vol. 70, pp. 272-281. From: DOI: 10.1016/j.wasman.2017.09.024

[9] GYUROV, S., MARINLOV, N., KOSTOVA, Y., RABADJIEVA, B., KOVACHEVA, D., TZVETKOVA, C., GENTSCHEVA, G and PENKOV, I. Technological scheme for copper slag processing. International Journal of Mineral Processing. 2017. vol 158. pp. 1-7. From: DOI: 10.10.1016/j.minpro.2016.11.008

[10] KAYEMBE, J.N, Wa KALENGA, M.K. and NYEMBWE, D.K. Effect of basicity and ferrosilicon addition matte formation from Ge-copper bearing slag. In Proceedings of Material Science and Technology Conference (MS\&T 2018). Columbus-Ohio/USA from $14^{\text {th }}$ to 18 th November 2018. pp. 1125-1131. 